\title{
Massive post-fire flowering events in a tropical mountain region of Brazil: high episodic supply of floral resources
}

\author{
Abel Augusto Conceição ${ }^{1,2}$, Thiago Gondim Alencar ${ }^{1}$, Jumara Marques Souza ${ }^{1}$, \\ Alan Daniel Cerqueira Moura ${ }^{1}$ and Gabriela Almeida Silva ${ }^{1}$
}

Received: 7 December, 2012. Accepted: 4 July, 2013

\begin{abstract}
The species Vellozia sincorana L.B.Sm. \& Ayensu is key to biodiversity conservation in the tropical mountain region of Brazil. The massive post-fire flowering of this endemic species provides a large, episodic supply of floral resources, mostly nectar, to animals.
\end{abstract}

Key words: Biodiversity conservation, Chapada Diamantina, nectar, rocky grasslands, Vellozia sincorana

Fire is one of the most important types of disturbance affecting tropical montane vegetation (Neves \& Conceição 2010; Gonçalves et al. 2011; Sherman et al. 2012). Chapada Diamantina National Park is located in a mountainous region of northeastern Brazil where many endemic species occur within grassland and savanna ecosystems, especially in rocky grasslands known as campos rupestres, where anthropogenic fires are recurrent (Gonçalves et al. 2011). The monocot family Velloziaceae is dominant on sandstones summits in the Chapada Diamantina region (Conceição et al. 2007a). The reproductive phenology of Velloziaceae responds to rainfall (Ayensu 1973; Conceição et al. 2007b) and to fire (Conceição \& Orr 2012), producing flowers that represent resources to many kinds of animals in rocky grassland communities in tropical montane regions (Ayensu 1973; Laudau et al. 1998; Jacobi \& Sarto 2007; Conceição \& Orr 2012). Here, we report the massive blooming of Vellozia sincorana L.B.Sm. \& Ayensu, locally known as candombá, a resprouting species endemic to the Chapada Diamantina region. Massive post-fire flowering in $V$. sincorana has been reported previously (Conceição \& Orr 2012). However, the availability of the reproductive resources associated with events of this type was not evaluated. The candombá has importance for the local population, because the branches are harvested and used as kindling to start cook fires (Conceição \& Orr 2012). Therefore, $V$. sincorana has a strong link with fire, because it is a source of fuel for humans and because it is dependent on fire to sexually reproduce and to provide resources for animals.

A wildfire occurred on 12 October 2011 in the rocky grasslands of the Serra do Candombá mountain range, in the Chapada Diamantina region (Fig. 1 and 2), at an elevation of approximately $1100 \mathrm{~m}$. Forty-two days after the wildfire, nearly all of the adult Vellozia sincorana individuals were flowering in the burned area. The result was a clear contrast between neighboring areas dominated by $V$. sincorana, the burned areas appearing purple due to flowering (referred to as the "purple scar") and the unburned areas remaining green (Fig. 2). Another fire occurred in the same mountain on 25-26 March 2012, burning almost all the area that had not burned in October 2011. Massive blooming was detected 35 days later. This study was conducted to evaluate the magnitude of $V$. sincorana flowering after burning and to quantify the nectar available as a result of the event.

During each flowering event, we estimated the area of the purple scar with global positioning satellite points, photographs, and ArcGIS software (Princeton University: https://www.princeton.edu/software/licenses/software/ $\operatorname{arcgis} /$ ). We estimated the total number of flowers per event by counting the flowers in ten $4-\mathrm{m}^{2}(2 \times 2 \mathrm{~m})$ plots randomly distributed in the purple scar area. On 4 February 2012, we collected 50 fruits (dry capsules) from the first fire event, in order to detect the presence or absence of insects in the first post-fire flowering event. We also collected the

\footnotetext{
${ }^{1}$ Universidade Estadual de Feira de Santana, Departamento de Ciências Biológicas, Laboratório Flora e Vegetação, Feira de Santana, Bahia, Brazil

${ }^{2}$ Author for correspondence: abel18@gmail.com
} 
Areas of Post-Fire Vellozia sincorana's Flowering, Chapada Diamantina, Brazil

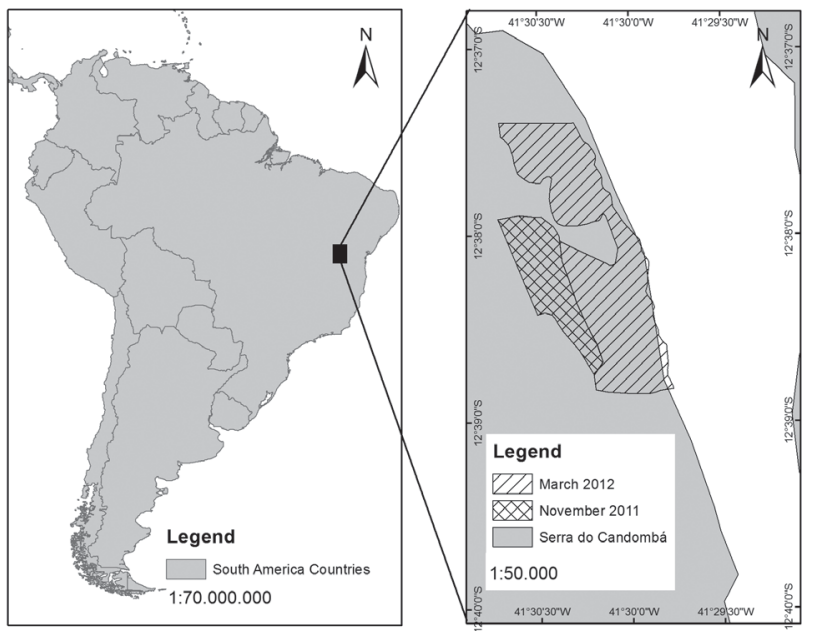

Figure 1. Map of study site, showing the areas of Serra do Candombá that had a high flowering concentration ('purple scar') after the first (October 2011) and second (March 2012) fire events, Chapada Diamantina, Bahia, Brazil.
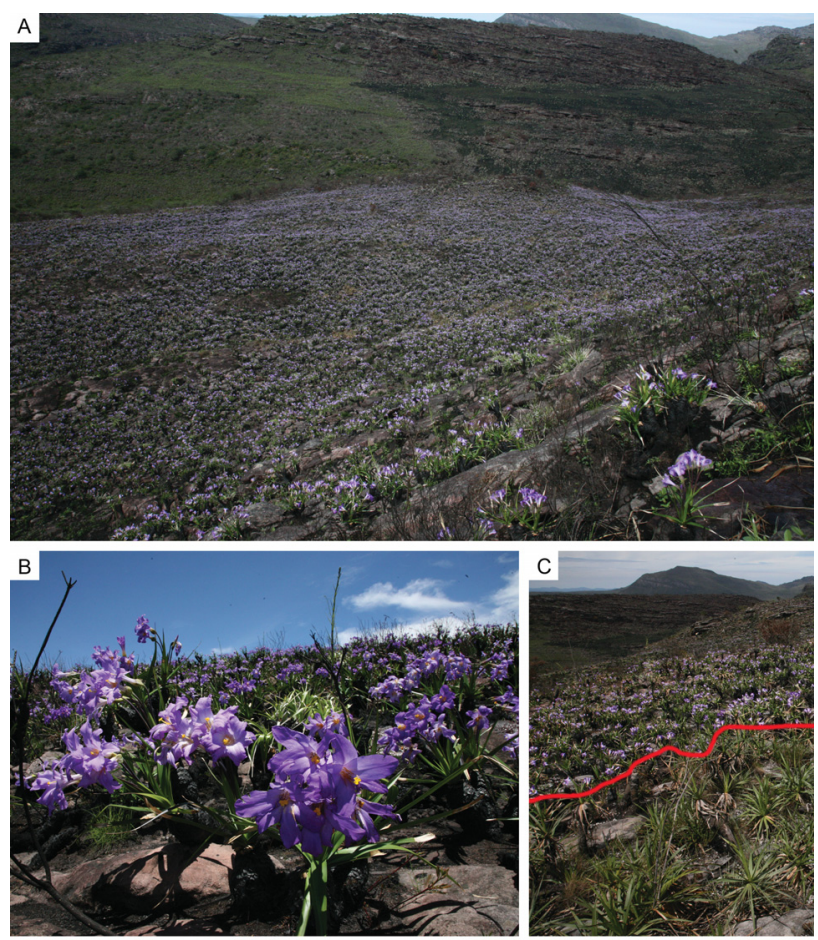

Figure 2. Vellozia sincorana L.B.Sm. \& Ayensu population in the Serra do Candombá on 26 November 2011 (burned on 12 October 2011). Chapada Diamantina National Park, Bahia, Brazil. A: part of the purple scar event. B: $V$. sincorana flowers. C: burned and unburned areas, the red line showing the approximate border between the two.

nectar of 40 flowers previously bagged from the second post-fire flowering event, in order to evaluate volume and sugar concentration. The area of the first purple scar was $57.6 \mathrm{ha}$, and the number of flowers in the plots ranged from 29 to 110 (mean, $67.9 \pm 24.1$ ). The area of the second purple scar was $176.1 \mathrm{ha}$, and the number of flowers in the plots ranged from 22 to 69 (mean, $50.2 \pm 16.9$ ). Based on the areas affected in the post-fire flowering events and the average number of flowers, approximately 9,792,000 flowers $\left(169,750\right.$ flowers.ha $\left.^{-1}\right)$ were produced in response to the first fire, and 22,150,000 flowers (125,500 flowers.ha $\left.{ }^{-1}\right)$ were produced in response to the second fire.

The mean Vellozia sincorana nectar volume in the purple scar areas evaluated was $26.2 \pm 8.8 \mu \mathrm{l}$ (range, 11-43 $\mu \mathrm{l}$ ), considerable higher than the $5.2 \pm 1.4 \mu \mathrm{l}$ reported for other species of Vellozia in rocky grasslands, which also present massive, short periods of flowering (Jacobi \& Sarto 2007). We estimated that approximately $579 \mathrm{~L}$ of nectar were produced during the second purple scar event. It was available to animals during the dry period, when resources are scarce. The mean sugar concentration in the flower nectar was $20.3 \pm 5.4 \%$ (range, $12-31 \%$ ), similar to the 19.7 $\pm 3.8 \%$ (range, 11-29\%) reported for the ornithophilous species Stachytarpheta glabra Cham. on ironstone outcrops (Jacobi \& Antonini 2008). However, this concentration is high when compared with the $11.6 \pm 3.3 \%$ reported for the flower nectar of another ornithophilous species, $V$. leptopetala Goeth. \& Henr., in rocky grasslands (Jacobi \& Sarto 2007). V. sincorana is a melittophilous species and the flowers of such species usually have more concentrated nectar (Baker 1975; Faegri \& Pijl 1980). Presumably, pollen is the main resource collected by bees from flowers of Vello$z i a$ species (Ayensu 1973), although that is not the case for the species studied here. Nectar production is important to pollination and makes food and water simultaneously available to floral visitors (Faegri \& Pijl 1980). Ants were often seen near the nectaries and most likely also consume the nectar of Vellozia spp. Ant colonies were observed on several branches of $V$. sincorana.

The large number of flowers and the abundance of Vellozia sincorana resources (nectar, pollen and blossoms) in these rocky grasslands are extremely rare phenomena, restricted to fire events and the reproductive period. During the field sampling, many insects were observed seeking pollen and nectar in the flowers, as is the case for other species of Vellozia (Ayensu 1973; Landau et al. 1998). In addition to bees, which apparently represented legitimate pollinators, other insect species obtained nectar by chewing holes in the corolla tube and hypanthium, and many flowers showed evidence of herbivore damage (Fig. 3). All 50 fruits collected contained insects, primarily beetles that remain within the capsules during a portion of their life. We collected individual insects at many stages of the life cycle, including larval phases.

The overall plant resources following a fire are extremely abundant because vegetative resources also increase after fires, as has been reported for the Brazilian savanna (Lopes \& Vasconcelos 2011). The second of the post-fire flowering events evaluated in the present study was distinctive because the central leaves and flowers on certain branches were destroyed by foraging horses. Although horses were 

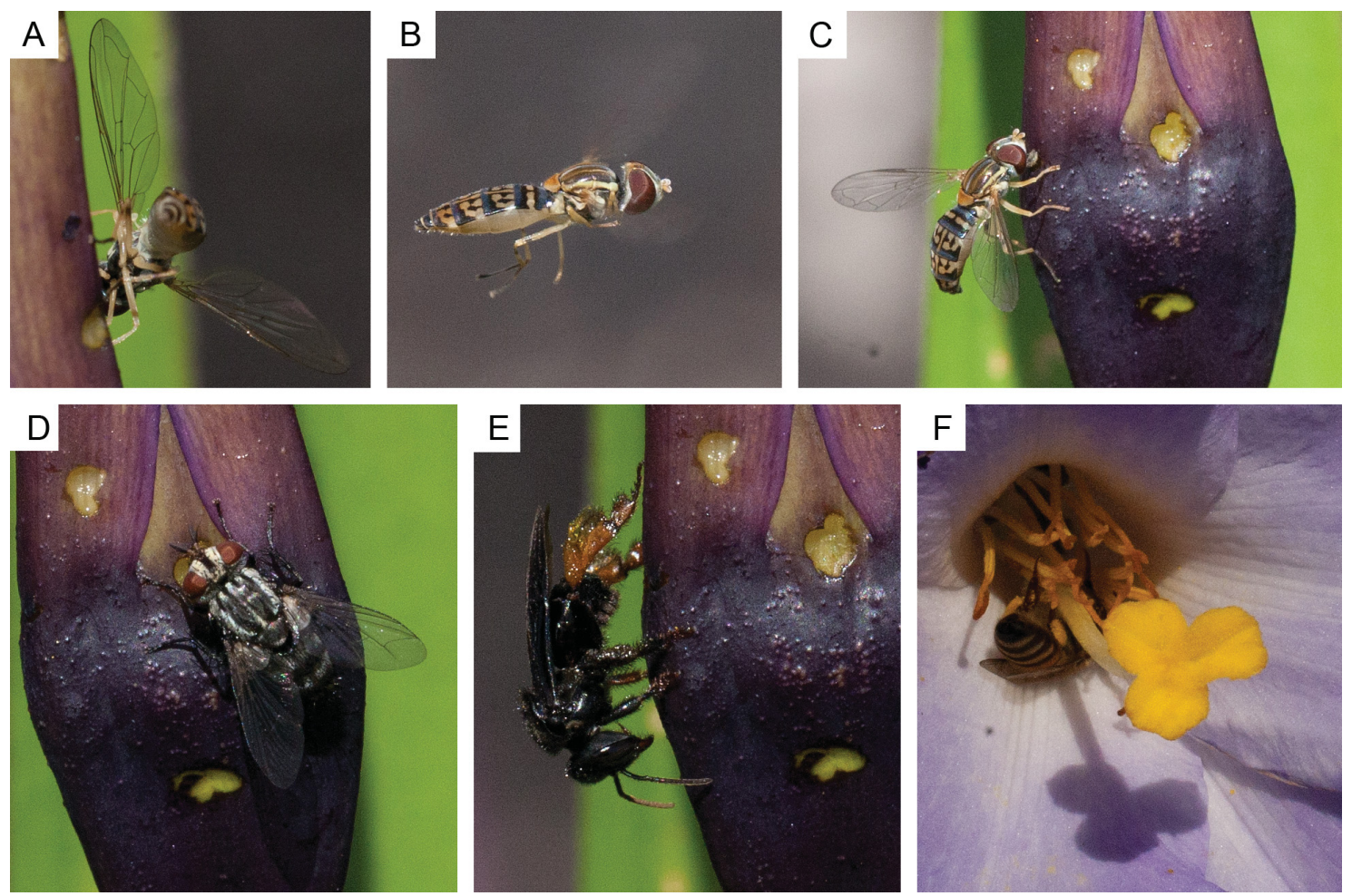

Figure 3. Insect floral visitors of Vellozia sincorana L.B.Sm. \& Ayensu in the Serra do Candombá. Chapada Diamantina National Park, Bahia, Brazil. A-C: Syrphidae. D: Sarcophagidae. E: Trigona sp. F: Apis mellifera.

seen in the mountains during the first event, few grazed the purple scar during the wet period, when the amount of green food available for grazing was greater than in the dry period. The grazing pressure during the second post-fire flowering event was higher than that during the first post-fire flowering event because the second event occurred during a part of the year that is very dry in northeastern Brazil. Food was available to grazers in this mountainous region because many plants had sprouted after the fire. The surrounding lower-altitude areas had been drier, and pasture was scarce in these areas. These observations demonstrate the importance of improving the control of exotic animals in Chapada Diamantina National Park.

Fires have marked effects on the quality of resources (reproductive $v s$. vegetative) and on the overall quantity of resources available in such habitats. It is probable that the architecture of Vellozia spp., which feature pseudostems and rosette leaves, protects the plants against lethal temperatures during fire events (Weiss 1906; Ayensu 1973). This fire-triggered phenomenon provides evidence of the influence of fire on the dynamics and functioning of the rocky grasslands dominated by $V$. sincorana. In the Brazilian savanna, fire was the main factor driving plant diversification on a regional scale in the late Miocene through the Pliocene and Pleistocene, from 9.8 to 0.4 Mya, coinciding with the dominance of C4 grasses (Simon et al. 2009). We hypothesize that the rocky grasslands investigated in this study were affected by fire during that period, by which the Velloziaceae, a Gondwana family, had already appeared (Mello-Silva et al. 2011).

The post-fire supply of floral resources is limited to a period of approximately two weeks (Conceição \& Orr 2012) and represents a highly episodic phenomenon that forms a component of a distinctive fire-dependent pattern. This pattern differs from the annual or continuous patterns of other species of Velloziaceae studied in the Chapada Diamantina region (Conceição et al. 2007b). The two post-fire flowering events evaluated in the present study occurred during two different seasons, the first occurring during the wet season ( $138.8 \mathrm{~mm}$ total rainfall in the 42 days between the fire and the flowering event) and the second occurring during the dry season (only $22.2 \mathrm{~mm}$ total rainfall in the 35 days between the fire and the flowering event). Meteorological data were obtained from the Orquidário do Pai Inácio meteorological station, in the city of Palmeiras, Bahia, 18 $\mathrm{km}$ from the Serra do Candombá. This contrast highlights the influence of fire in these communities and the high efficiency of water uptake in Vellozia sincorana, a species that can achieve massive post-fire flowering and high nectar production even during the dry season.

In conclusion, Vellozia sincorana is key to biodiversity conservation in Chapada Diamantina National Park. More studies are needed in order to increase the knowledge of the impact that the cyclic fire-dependent availability of floral resources to animals has on the dynamics of these communities. 


\section{Acknowledgments}

The authors would like to thank F.G. Moreira, for the assistance in the field work, as well as I. B. Schimdt and A. Rapini for their helpful comments and revisions, and to Instituto Chico Mendes de Conservação da Biodiversidade for the license to work in Chapada Diamantina National Park. This study received financial support from the Brazilian Conselho Nacional de Desenvolvimento Científico e Tecnológico (CNPq, National Council for Scientific and Technological Development; research grant no. 311301/2011-8 to AAC, general research grant no. 556820/2011-0 and Pesquisa Ecológica de Longa Duração [PELD, Long-term Ecological Research] grant no. 59/2009) and the Fundação de Amparo à Pesquisa do Estado da Bahia (FAPESB, Foundation for the Support of Research in the State of Bahia; grant no. TO 26/2011).

\section{References}

Ayensu, E.S. 1973. Biological and morphological aspects of the Velloziaceae. Biotropica 5: 135-149.

Baker, H.G. 1975. Sugar concentrations in nectars from hummingbird flowers. Biotropica 7: 37-41.

Conceição, A.A.; Funch, L.S. \& Pirani, J.R. 2007b. Reproductive phenology, pollination and seed dispersal syndromes on sandstone outcrop vegetation in the "Chapada Diamantina", northeast Brazil: population and community analyses. Revista Brasileira de Botânica 30: 475-485.

Conceição, A.A.; Pirani, J.R. \& Meirelles, S.T. 2007a. Floristics, structure and soil of insular vegetation in four quartzite-sandstone outcrops of "Chapada Diamantina", northeast Brazil. Revista Brasileira de Botânica 30: 641-655.
Conceição, A.A. \& Orr, B.J. 2012. Post-fire flowering and fruiting in the caulescent rosette Vellozia sincorana, an endemic plant to the Northeast of Brazil. Acta Botanica Brasilica 26: 94-100.

Faegri, K. \& van der Pijl, L. 1980. The principles of pollination ecology. Oxford, Pergamon Press.

Gonçalves, C.N.; Mesquita, F.W.; Lima, N.R.G.; Coslope, L.A. \& Lintomen, B.S. 2011. Recorrência dos incêndios e fitossociologia da vegetação em áreas com diferentes regimes de queima no Parque Nacional da Chapada Diamantina. Biodiversidade Brasileira 1: 161-179.

Jacobi, C.M. \& Sarto, M.C.L. 2007. Pollination of two species of Vellozia (Velloziaceae) from high-altitude quartzitic grasslands, Brazil. Acta Botanica Brasilica 21: 325-333.

Jacobi, C.M. \& Antonini, Y. 2008. Pollinators and defense of Stachytarpheta glabra (Verbenaceae) nectar resources by hummingbird Colibri serrirostris (Trochilidae) on ironstone outcrops in south-east Brazil. Journal of Tropical Ecology 24: 301-308.

Landau, E.C.; Gonçalves-Alvim, S.J.; Fagundes, M. \& Fernandes, G.W. 1998. Riqueza e abundância de herbívoros em flores de Vellozia nivea (Velloziaceae). Acta Botanica Brasilica 12: 403-409.

Lopes, C.T. \& Vasconcelos, H.L. 2011. Fire increases insect herbivory in a Neotropical savanna. Biotropica 43: 612-618.

Mello-Silva, R.; Santos, D.Y.A.C.; Salatino, M.L.F.; Motta, L.B.; Cattai, M.B.; Sasaki, D.; Lovo, J.; Pita, P.B.; Rocini, C.; Rodrigues, C.D.N.; Zarrei, M. \& Chase, M.W. 2011. Five vicarious genera from Gondwana: the Velloziaceae as shown by molecules and morphology. Annals of Botany 108: 87-102.

Neves, S.P.S. \& Conceição, A.A. 2010. Campo rupestre recém-queimado na Chapada Diamantina, Bahia, Brasil: plantas de rebrota e sementes, com espécies endêmicas na rocha. Acta Botanica Brasilica 24: 697-707.

Sherman, R.E.; Fahey, T.J.; Martin, P.H. \& Battles, J.J. 2012. Patterns of growth, recruitment, mortality and biomass across an altitudinal gradient in a neotropical montane forest, Dominican Republic. Journal of Tropical Ecology 28: 483-495.

Simon, M.F.; Grether, R.; Queiroz, L.P.; Skema, C.; Pennington, R.T. \& Hughes, C.E. 2009. Recent assembly of the Cerrado, a neotropical plant diversity hotspot, by in situ evolution of adaptations of fire. Proceedings of National Academy of Sciences of the United States of America 48: 20359-20364.

Weiss, F.E. 1906. Sketches of vegetation at home and abroad. New Phytologist 5: 1-9. 